\title{
Náhodně zjištěná chronická disekce descendentní aorty při MR vyšetření srdce nemocného s hypertrofickou kardiomyopatií
}

\author{
Martin Mašek1, Andrea Burgetová', Manuela Vaněčková', Jana Vlková', Aleš Král', Petr Vařejka², Jan Malecha \\ a Tomáš Paleček ${ }^{2}$ \\ ' Radiodiagnostická klinika, Všeobecná fakultní nemocnice a 1. lékařská fakulta Univerzity Karlovy, Praha, \\ 2II. interní klinika kardiologie a angiologie, Všeobecná fakultní nemocnice a 1. lékařská fakulta Univerzity Karlovy, Praha, \\ ${ }^{3}$ Ordinace pro choroby srdce, s.r. o., Chomutov, Česká republika
}

Adresa: MUDr. Tomáš Paleček, Ph.D., II. interní klinika kardiologie a angiologie, VFN a 1. LF UK, U Nemocnice 2, 12800 Praha 2, Česká republika, e-mail: tpalec@lf1.cuni.cz

Pětačtyřicetiletý muž s anamnézou jeden rok léčené arteriální hypertenze byl v listopadu 2009 přijat na interní oddělení spádové nemocnice pro náhle vzniklé bolesti mezi lopatkami, které recidivovaly i v průběhu hospitalizace a byly zhodnoceny jako vertebrogenního původu. Po propuštění $\mathrm{z}$ nemocnice se zaregistroval $\mathrm{u}$ ambulantního kardiologa, který v lednu 2010 echokardiograficky zjistil výraznou hypertrofii levé komory s významnou dynamickou klidovou obstrukcí výtokového traktu a s diagnózou hypertrofické obstrukční kardiomyopatie odeslal nemocného k vyšetření na specializované pracoviště.

Komplex ambulantních vyšetření naplánovaných do jednoho dne byl zahájen krevními náběry a natočením křivky EKG, kde byl př́tomen sinusový rytmus se známkami hypertrofie a zatížení levé komory. Poté následovalo provedení magnetické rezonance srdce. Vyšetření bylo zahájeno scany v sekvenci CINE-BTFE ve vertikální dlouhé ose a následně horizontální dlouhé ose, kdy získané scany jednak potvrdily obraz hypertrofické kardiomyopatie (maximální tlouštka septa $21 \mathrm{~mm}$, tlouštka ostatních stěn levé komory $13 \mathrm{~mm}$ ), ale jako překvapivý a závažný vedlejší nález byla na získaných scanech $\mathrm{v}$ obou rovinách zobrazena též disekce sestupné aorty (obrázky 1-3). Ihned byla doplněna krátká cílená anamnéza, jež ukázala, že výše uvedené bolesti zad se u nemocného doposud intermitentně objevují a mohly by být projevem aortální disekce. $\mathrm{V}$ rámci vyšetření zaměřeného na diagnózu hypertrofické kardiomyopatie byly proto doplněny již jen scany v sekvenci CINE-BTFE v krátké ose, na nichž byla kvantifikována normální ejekční frakce levé komory $70 \%$, a dále scan se zaměřením na výtokový trakt levé komory, který potvrdil dopředný pohyb předního mitrálního cípu vedoucí k významné dynamické obstrukci
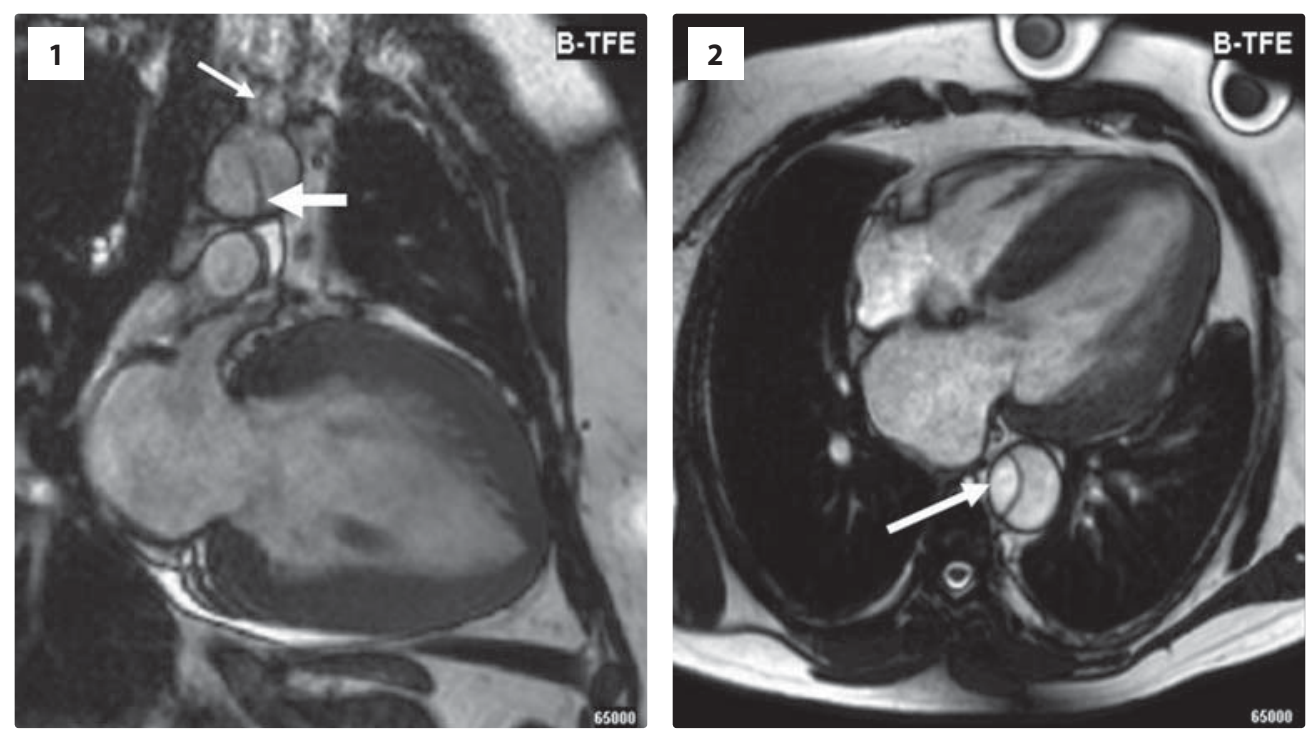

Obrázek 1 MR srdce, CINE-BTFE, řez levou komorou ve vertikální dlouhé ose; kromě hypertrofie myokardu je patrna disekce aorty (šipka) zasahující do odstupu levé arteria subclavia (tenká šipka)

Obrázek 2 MR srdce, CINE-BTFE; disekce aorty je patrna i na řezu $v$ horizontální dlouhé ose (šipka) 

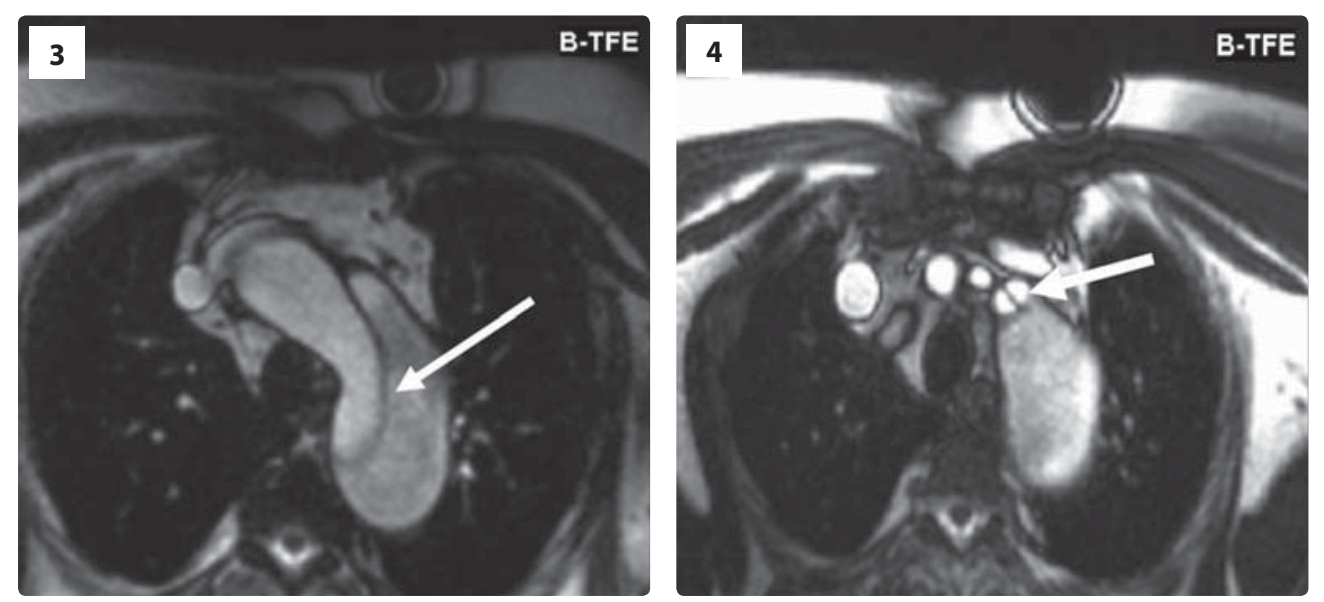

Obrázek 3 MR srdce, CINE-BTFE, transverzální řez v úrovni aortálního oblouku, disekce označena šipkou

Obrázek 4 MR srdce, CINE-BTFE, transverzální řez v úrovni odstupů tepen aortálního oblouku, disekce přechází do odstupu levostranné a. subclavia (šipka)
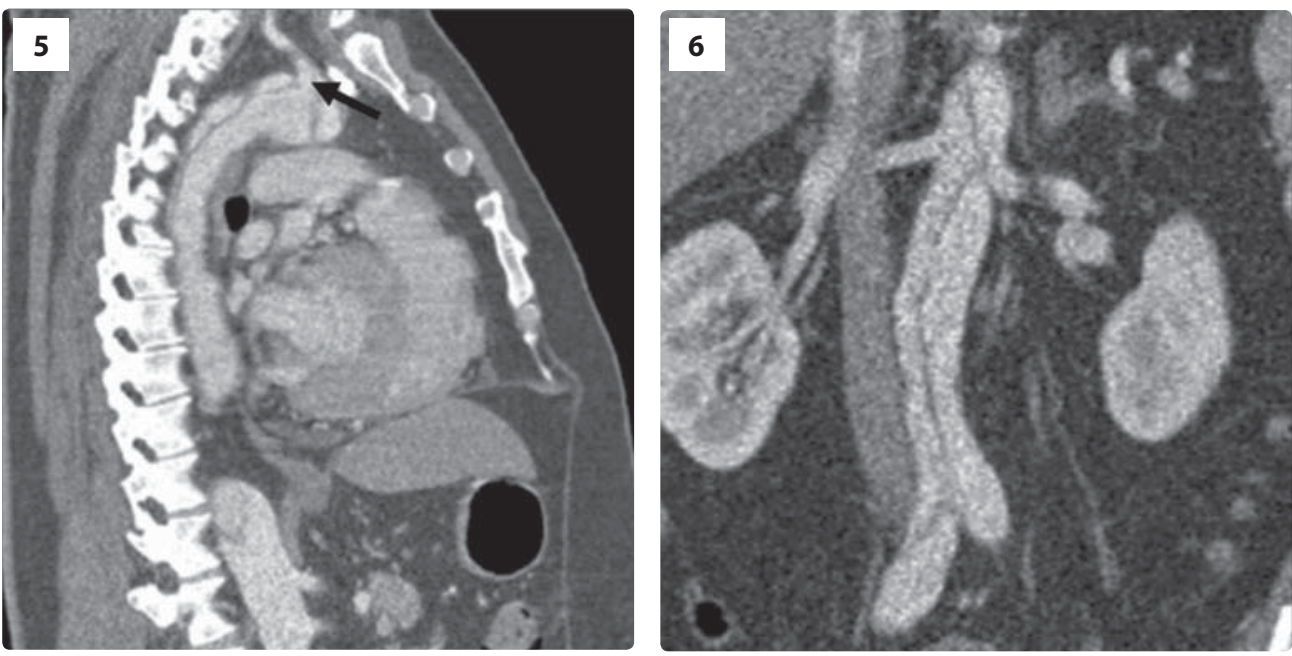

Obrázek 5 CT angiografie, řez v sagitální rovině zobrazující disekci sestupné aorty zasahující do odstupu levostranné a. subclavia (šipka)

Obrázek 6 CT angiografie abdominální aorty, koronární řez. Pravá a. renalis odstupuje z pravého a levá a. renalis $z$ falešného lumen. Disekce pokračuje na společné ilické tepny.
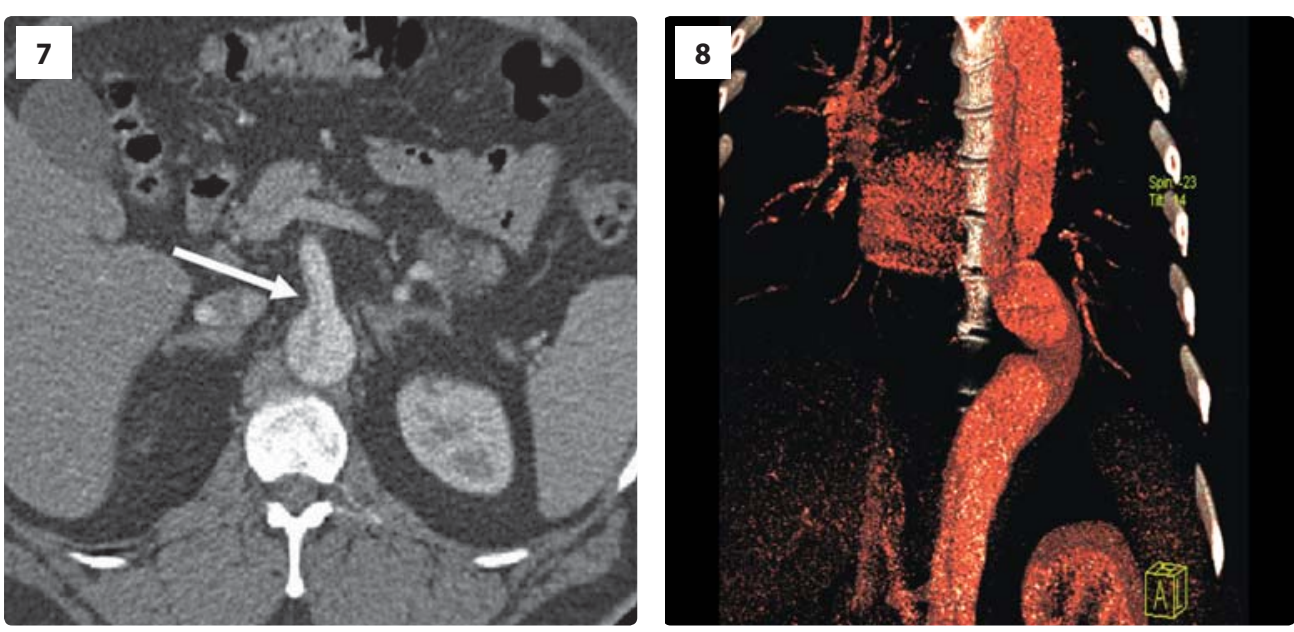

Obrázek 7 CT angiografie abdominální aorty, transverzální řez, disekce zasahující do odstupu truncus coeliacus (šipka)

Obrázek 8 CT angiografie, VRT rekonstrukce zachycující disekci descendentní aorty v thorakálním i abdominálním úseku

výtoku levé komory (klidový gradient $100 \mathrm{~mm} \mathrm{Hg}$ při následném echokardiografickém vyšetření). Vyšetřovací protokol byl poté zaměřen na stanovení rozsahu disekce aorty. Doplněné scany v CINE-BTFE v transverzální rovině prokázaly počátek disekce descendentní aorty v místě odstupu levostranné arteria subclavia, do níž disekce rovněž zasahovala (obrázky 4, 5). Nemocný byl po MR vyšetření hospitalizován na jednotce intenzivní angiologické péče a bylo u něj doplněno jícnové echokardiografické vyšetření a CT angiografické vyšetření aorty. CT angiografie jednak potvrdila nález MR ve smyslu proximálního rozsahu disekce (obrázek 6), jednak byl přesně určen kaudální rozsah disekce až na obě společné ilické tepny. Viscerální tepny odstupující jak $\mathrm{z}$ pravého, tak $\mathrm{z}$ nepravého lumen byly dobře plněny (obrázky 7,8 ). Retroperitoneální hematom ani jiné komplikace disekce CT vyšetření neprokázalo. Finálně byla stanovena diagnóza chronické disekce typu B dle Stanfordské klasifikace. Vzhledem k tomu, že pacient $\mathrm{v}$ době průkazu disekce netrpěl žádnými závažnými klinickými symptomy, byl nadále zvolen konzervativní postup se zaměřením na účinnou antihypertenzní léčbu; intervenční angiologická léčba $v$ podobě implantace stentgraftu nebyla s ohledem na odstupy viscerálních tepen z obou lumen disekce indikována. 